\title{
Changes in Glycine Immunoreactivity in the Rat Superior Olivary Complex Following Deafness
}

\author{
ERIC D. BURAS, ${ }^{1}$ AVRIL GENENE HOLT, ${ }^{1 *}$ RONALD D. GRIFFITH, ${ }^{1}$ \\ MIKIYA ASAKO, ${ }^{1,2}$ AND RICHARD A. ALTSCHULER ${ }^{1,3}$ \\ ${ }^{1}$ Kresge Hearing Research Institute, Department of Otolaryngology/Head Neck Surgery, \\ University of Michigan, Ann Arbor, Michigan 48109 \\ ${ }^{2}$ Department of Otolaryngology, Kansai Medical University, Osaka 570-8506, Japan \\ ${ }^{3}$ Department of Cell and Developmental Biology, University of Michigan, \\ Ann Arbor, Michigan 48109
}

\begin{abstract}
The balance between inhibitory and excitatory amino acid neurotransmitters contributes to the control of normal functioning of the auditory brainstem. Changes in the level of neuronal activity within the auditory brainstem pathways influence the balance between inhibition and excitation. Activity-dependent plasticity in the auditory pathways can be studied by creating a large decrease in activity through peripheral deafening. Deafnessrelated decreases in GABA have previously been shown in the inferior colliculus. However, glycine is a more prevalent inhibitory transmitter in the mature superior olivary complex (SOC). The present study therefore examined if there were deafness-related changes in glycine in the SOC using postembedding immunocytochemistry. Animals were bilaterally deafened by an intrascalar injection of neomycin. Five nuclei in the SOC, the lateral superior olive (LSO), superior paraolivary nucleus (SPoN), and the medial, lateral, and ventral nuclei of the trapezoid body (MNTB, LNTB, and VNTB) were examined 14 days following the deafening and compared to normal hearing age-matched controls. The LSO and SPoN were divided into high and low frequency regions. The number of glycine immunoreactive puncta on the somata of principal cells showed significant decreases in all regions assessed, with changes ranging from $50 \%$ in the VNTB to $23 \%$ in the LSO. J. Comp. Neurol. 494:179-189, 2006. ๑ 2005 Wiley-Liss, Inc.
\end{abstract}

Indexing terms: auditory; brainstem; neomycin; superior olivary complex

Increases or decreases in activity induce plastic changes in the mature auditory pathways (recently reviewed by Syka, 2002; and more generally by Møller 2001, 2005). There is deafness-associated plasticity at the synaptic level in the mature auditory brainstem, with changes in amino acid neurotransmitters and receptors (Bledsoe et al., 1995; Potashner et al., 1997, 2000; Milbrandt et al., 1997; Benson et al., 1997; Ryugo et al., 1998; Caspary et al., 1999; Helfert et al., 1999; Mossop et al., 2000; Nakagawa et al., 2000; Sato et al., 2000a,b; Willott et al., 2000; Holt et al., 2005), in ion channels (Macica et al., 2003; Lu et al., 2004; von Hehn et al., 2004), as well as in synapserelated proteins such as protein kinases, Gap43, calbindin, ERK, SAPK, NT3 and BDNF (Idrizbegovic et al., 1998; Garcia et al., 2000; Illing and Michler, 2001; Suneja and Potashner, 2003b). Thus, there is a resulting influence on the balance between excitation and inhibition reflected in changes in neuronal response profiles (Bledsoe et al., 1995; Caspary et al., 1995; Francis and Manis, 2000; Kaltenbach and Afman, 2000; Mossop et al., 2000; Salvi et al., 2000; Syka et al., 2000; Syka and Rybalko, 2000) as well as in changes in tonotopic maps (Willott et al., 1982,

Grant sponsor: National Institutes of Health/National Institute on Deafness and Other Communication Disorders; Grant number: DC00383, Grant number: NIH-1F32GM013553 (Postdoctoral Fellowship to A.G.H.); Grant number: NIH-P30 DC05188.

The first two authors contributed equally to the study.

*Correspondence to: Avril Genene Holt, KHRI, Department of Otolaryngology, The University of Michigan, 1301 East Ann St., Ann Arbor, M 48109-0506. E-mail: shuler@umich.edu

Received 19 April 2005; Revised 22 June 2005; Accepted 29 July 2005 DOI 10.1002/cne.20795

Published online in Wiley InterScience (www.interscience.wiley.com). 
1993; Robertson and Irvine, 1989; Schwartz et al., 1993; Rajan and Irvine, 1998; Salvi et al., 1999; Nagase et al., 2000). A shift towards decreased inhibition and increased excitation has been reported in the CIC (Vale and Sanes, 2002) associated with decreases in GABA release (Bledsoe et al., 1995) and decreases in the GABA synthesizing enzyme GAD (Mossop et al., 2000). Glycine is a major inhibitory transmitter in the superior olivary complex (SOC) (Caspary et al., 1987, 1994; Wickesberg and Oertel, 1990; Grothe and Sanes, 1993; Wu and Kelly, 1994) and decreases in glycine release have been reported in specific SOC nuclei following deafening (Suneja et al., 1998). This would suggest that there may be an activity-dependent, deafness-associated decrease in glycine in the SOC. The present study, therefore, employed quantitative immunocytochemistry to compare the number of glycineimmunoreactive (-IR) axo-somatic puncta on neurons in five SOC regions: the lateral superior olive (LSO), medial, lateral, and ventral nuclei of the trapezoid body (MNTB, LNTB, and VNTB), and superior paraolivary nucleus $(\mathrm{SPoN})$ in normal hearing and 14-day bilaterally deafened rats.

\section{MATERIALS AND METHODS}

Adult, female Sprague Dawley rats (Charles River Laboratories, Wilmington, MA) were used in this study. Rats weighed between 200-300 g at the time of surgery and were at least 2 months old. The experimental (deafened) group ( $\mathrm{n}=5$ ) was assessed 14 days following bilateral deafening via perfusion of $30 \mu \mathrm{l}$ of $30 \%$ neomycin through the round window of the cochlea. The animals in the control group were age-matched and had normal hearing $(\mathrm{n}=5)$.

\section{Surgery}

Surgical procedures were performed under aseptic conditions and normal body temperature was maintained throughout the procedure. Animals were anesthetized intramuscularly (i.m.) with a mixture of Ana Sed $(8 \mathrm{mg} / \mathrm{kg}$ xylazine sterile solution $20 \mathrm{mg} / \mathrm{ml}$; Ben Venue Laboratories, Bedford, $\mathrm{OH}$ ) and Ketaset $(75 \mathrm{mg} / \mathrm{kg}$ ketamine- $\mathrm{HCl}$ sterile solution $100 \mathrm{mg} / \mathrm{ml}$; Fort Dodge Animal Health, Fort Dodge, IA). Local injections of $1 \%$ lidocaine-HCl solution (Abbott Laboratories, North Chicago, IL) were made at the site of each surgical incision. The lateral wall of each bulla was opened and $30 \mu \mathrm{L}$ of $30 \%$ neomycin solution was slowly injected through the cochlear round window using a 50- $\mu$ l Hamilton syringe. The total injection time was $\sim 2$ minutes per ear. Following surgery, animals were injected subcutaneously with $1 \mathrm{ml}$ sterile $0.9 \%$ sodium chloride-HCl solution (Abbott Laboratories) and allowed to recover under a heating lamp. These and other procedures performed on animals were in accordance with the requirements of the University Committee on the Use and Care of Animals and in accordance with all federal and state laws.

\section{Auditory brainstem responses}

Hearing was assessed by ABR measures at 2, 10, and 20 $\mathrm{kHz}$ in all animals at the beginning of the study and only those with hearing in the normal range $(2 \mathrm{kHz}-15 \mathrm{~dB}, 10$ $\mathrm{kHz}-15 \mathrm{~dB}$, and $20 \mathrm{kHz}-16 \mathrm{~dB}$ ) were included in the study. Animals were anesthetized $(8 \mathrm{mg} / \mathrm{kg}$ xylazine sterile solution $20 \mathrm{mg} / \mathrm{ml}$; and $75 \mathrm{mg} / \mathrm{kg}$ ketamine-HCl sterile solution $100 \mathrm{mg} / \mathrm{ml}$ ) and a transducer was placed in the ear canal that delivered a tone at varying intensities. The neurologic response from the auditory system was recorded from subdermal needle electrodes placed on top of the head, nose, and thigh. A second measure of hearing was done just prior to perfusion for animals in the deafness groups. An $80 \mathrm{~dB}$ shift from the normal control threshold averaged across the frequencies was considered necessary for continued inclusion in the study. At each frequency tested deafened animals were nonresponsive up to $105 \mathrm{~dB}$.

\section{Fixation and tissue processing}

Animals were anesthetized by subcutaneous (s.c.) injection of chloral hydrate and perfused transcardially with a rinse of $\mathrm{Ca}^{2+}$-free Ringer's variant followed by a fixative containing $2 \%$ paraformaldehyde and $1.25 \%$ glutaraldehyde in $0.12 \mathrm{M}$ sodium phosphate buffer.

After perfusion, brains were removed and postfixed for 90 minutes in the same solution. The tissue was cut coronally into $150-\mu \mathrm{m}$ sections using a vibrating microtome (Vibratome, St. Louis, MO). The sections were then incubated in $1 \%$ osmium tetroxide $\left(\mathrm{OsO}_{4}\right)$ on ice for 45 minutes. This and subsequent steps were carried out in the dark. The sections were then incubated in $2 \%$ uranyl acetate and dehydrated through a series of graded ethanol washes. Following dehydration, sections were incubated in a 1:1 mixture of EPON 812 and propylene oxide on a vertical rotator. The sections were next incubated in $100 \%$ EPON 812 overnight. Following this incubation, sections were placed between sheets of Mylar and incubated for 48 hours at $60^{\circ} \mathrm{C}$. Following polymerization, all sections containing the SOC were examined. A comparable section (based on anatomical markers) from mid-rostrocaudal SOC containing all of the primary SOC nuclei was selected from each animal for further processing. The ventral portion of this section containing all five nuclei was dissected out of the Mylar with a scalpel and affixed to an EPON 812 blank. One- $\mu \mathrm{m}$ sections were cut using an ultramicrotome and systematic sampling was followed as described below. Five 1- $\mu \mathrm{m}$ sections (separated by $12 \mu \mathrm{m}$; the $1 \mathrm{st}, 13 \mathrm{th}, 25 \mathrm{th}, 37 \mathrm{th}$, and 49 th in the series) were analyzed from each rat. The $12-\mu \mathrm{m}$ interval was chosen so that the space between sections would be larger than the size of an SOC principal cell nucleus. With the criteria that the profile of a neuron needed to contain a nucleus to be assessed, this ensured that any given neuron would only be analyzed once. Five adjacent $1-\mu \mathrm{m}$ sections (the 2nd, 14th, 26th, 39th, and 50th in the series) received a Nissl stain (Toluidine blue) for anatomical reference.

\section{Immunocytochemistry}

The five sections selected for immunocytochemistry were rehydrated in solutions of decreasing ethanol concentration $(100 \%, 70 \%, 50 \%, 35 \%)$. The sections were then treated for 40 minutes in sodium ethoxide for "etching," rehydrated, and then treated in $1 \%$ sodium periodate for 10 min for "bleaching." The standard protocol for immunocytochemistry using the ABC Elite Kit (Vector Laboratories, Burlingame, CA) was then followed. Briefly, the sections were blocked for 20 minutes at room temperature in a solution containing 5\% normal goat serum (NGS) and 0.5 M Tris. Primary antibody incubation proceeded overnight in a 1:1,200 dilution of polyclonal rabbit antisera against bovine serum albumin-glutaraldehyde conju- 

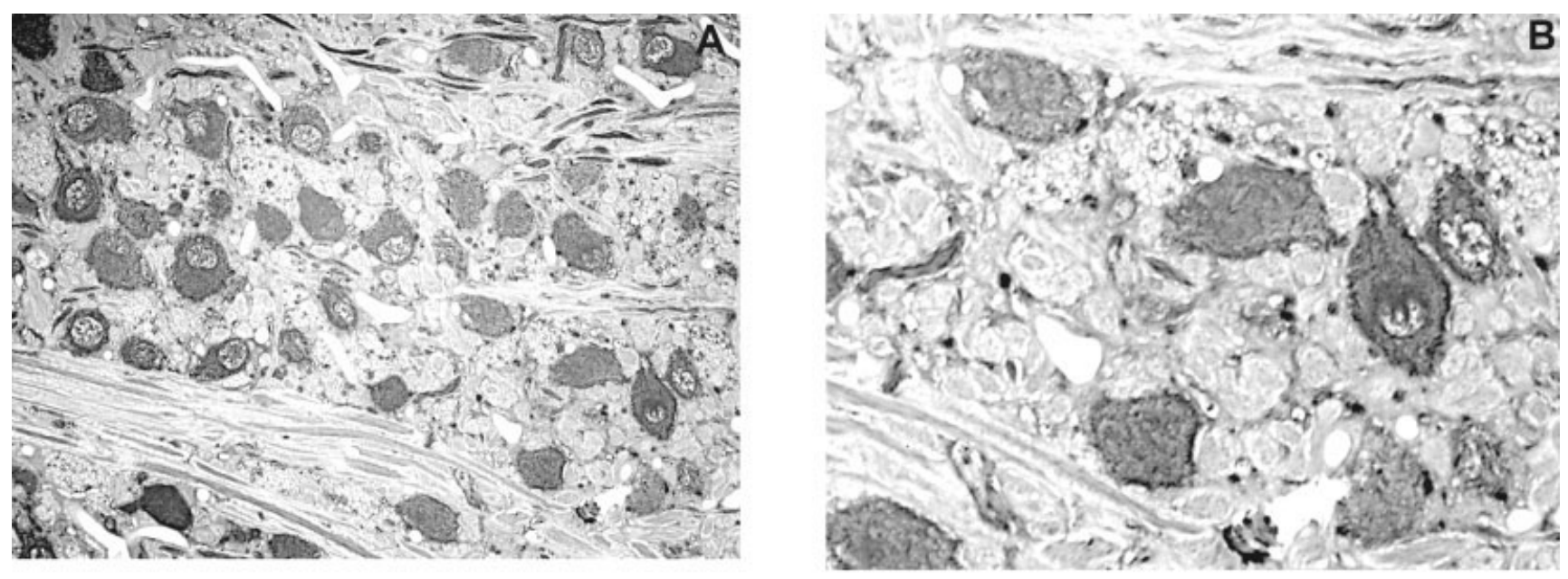

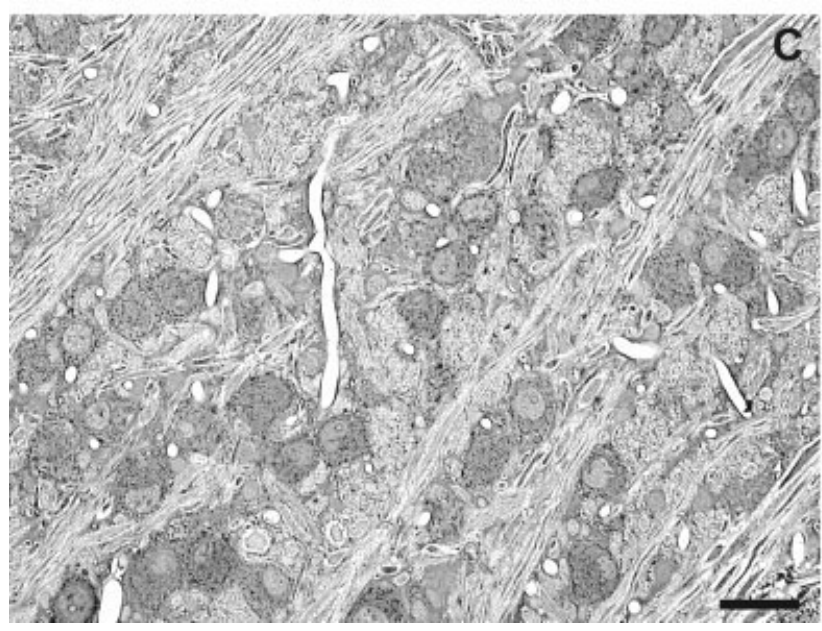

Fig. 1. Representative photomicrographs of Gly-IR staining in the MNTB from normal hearing $(\mathbf{A}, \mathbf{B})$ and 14-day deaf $(\mathbf{C , D})$ rats. B and $\mathrm{D}$ are enlargements of regions from A and C. Many of the glycineimmunolabeled principal cells of the MNTB from normal haring an-

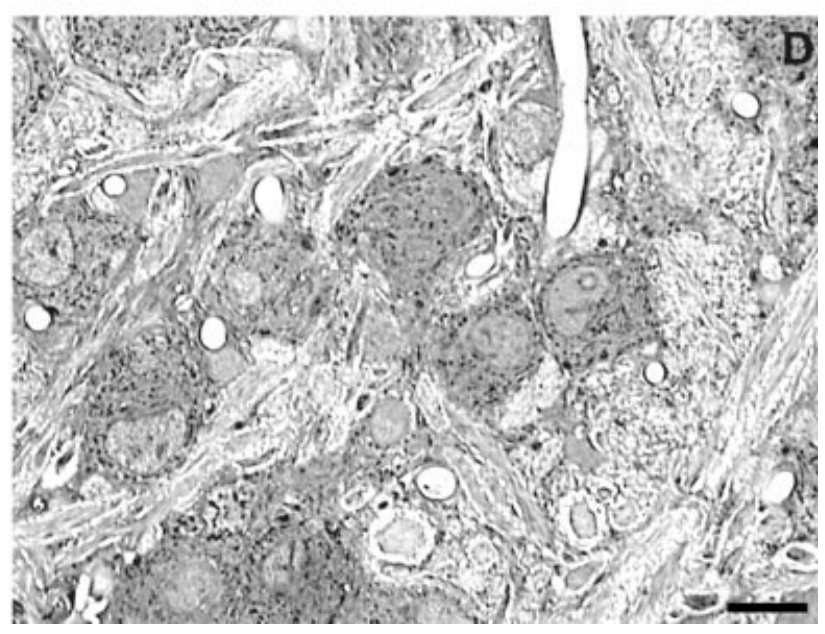

imals (A,B) are surrounded by Gly-IR puncta. Following 14 days of deafness the number of glycine immunoreactive axosomatic puncta significantly decreases. Scale bars $=30 \mu \mathrm{m}$ in $\mathrm{C}$ (applies to A,C); 15 $\mu \mathrm{m}$ in $\mathrm{D}$ (applies to $\mathrm{B}, \mathrm{D})$. gates of glycine (antibody \#139 Chemicon International, Temecula, CA) at $4^{\circ} \mathrm{C}$. The specificity of this antibody has been previously verified in the retina (Kalloniatis and Fletcher, 1993) and in the auditory brainstem (Spirou and Berrebi, 1997). In the auditory system, sections containing the glycine-rich MNTB were incubated with glycine antibody preadsorbed overnight with $2-20 \mathrm{mM}$ of glutaraldehyde-conjugated glycine or GABA antigen (Storm-Mathisen and Otterson, 1990). The glycine antibody did not show any cross-reactivity with GABA and glycine labeling was eliminated with an excess of the antigen. Sections were rinsed in 0.5 M Tris and incubated in goat antirabbit secondary antibody diluted 1:100. Following rinses in $0.5 \mathrm{M}$ Tris, the tissue was incubated for 1 hour in the $\mathrm{ABC}$ solution (Vector). Sections were incubated with $0.05 \%$ diaminobenzidine (DAB) in $80 \mathrm{ml}$ PBS solution containing $200 \mu \mathrm{l}$ of $30 \%$ hydrogen peroxide. Sections were incubated in DAB for 3 minutes. Usually, by the 3-minute time point the neurons in the MNTB of normal hearing animals could be clearly distinguished as being labeled above background. The DAB reaction was stopped by removing the DAB solution from the slide holder and rinsing several times with $\mathrm{ddH}_{2} \mathrm{O}$. Following these rinses, sections were dried with compressed air and dehydrated in solutions of increasing ethanol concentration: $50 \%, 70 \%, 80 \%$, 95\%, 100\%. Finally, sections were incubated in a xylene solution and covered using a Permount xylene solution.

\section{Image acquisition and analysis}

The middle three $1-\mu \mathrm{m}$ sections (the 13th, 25th, and 37th) from the set of five immunostained sections (the 1st, 13th, 25th, 37th, and 49th) were used for quantitative analysis for each of the five rats in each group. If methodological damage to the section prevented accurate assessment of any SOC nuclei in one of these sections, the better-preserved of the remaining two immunostained sections (the 1st or 49th) was substituted for the analysis. 

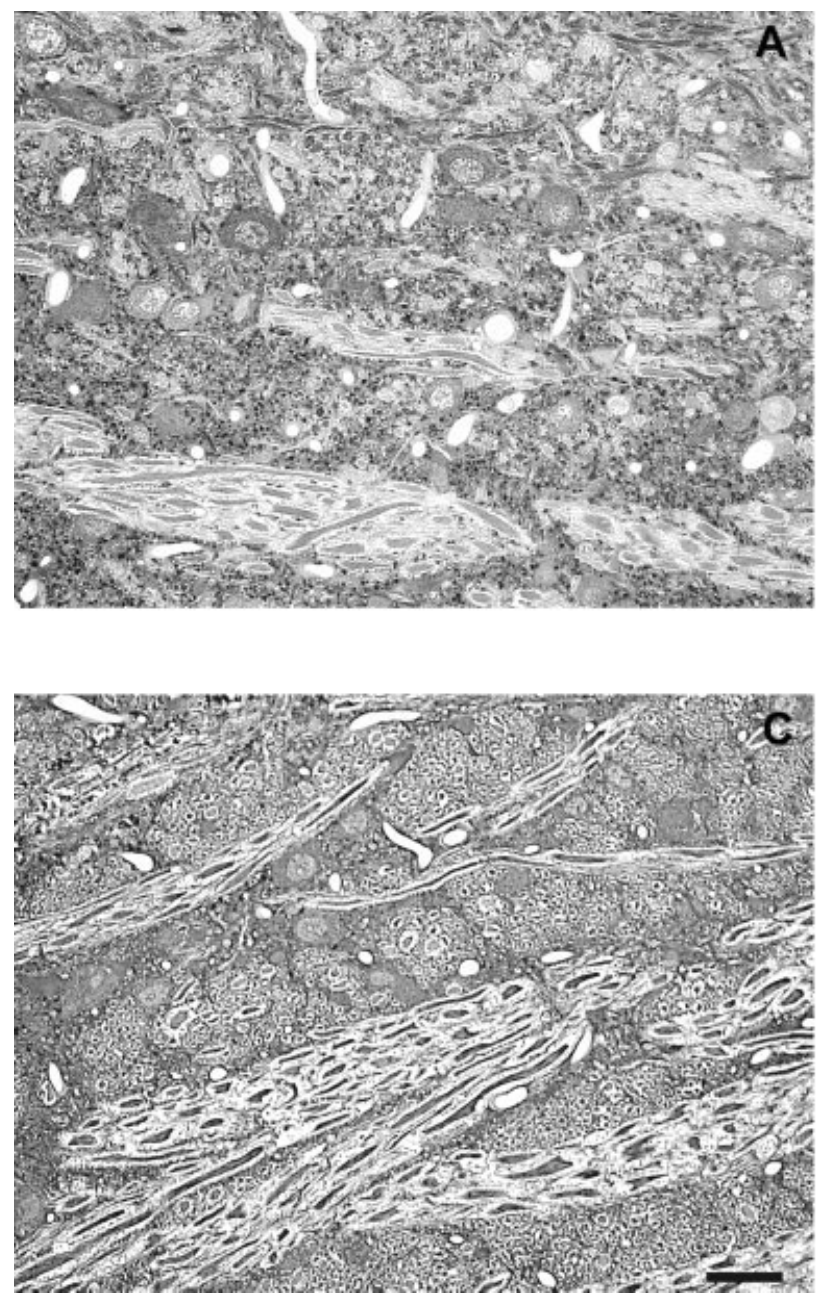

Fig. 2. Representative photomicrographs of Gly-IR staining in the VNTB from normal hearing $(\mathbf{A}, \mathbf{B})$ and 14-day deaf $(\mathbf{C}, \mathbf{D})$ rats. B and $\mathrm{D}$ are enlargements of regions from A and C. In the VNTB from normal animals there is a mixture of Gly-IR and Gly-immunonegative
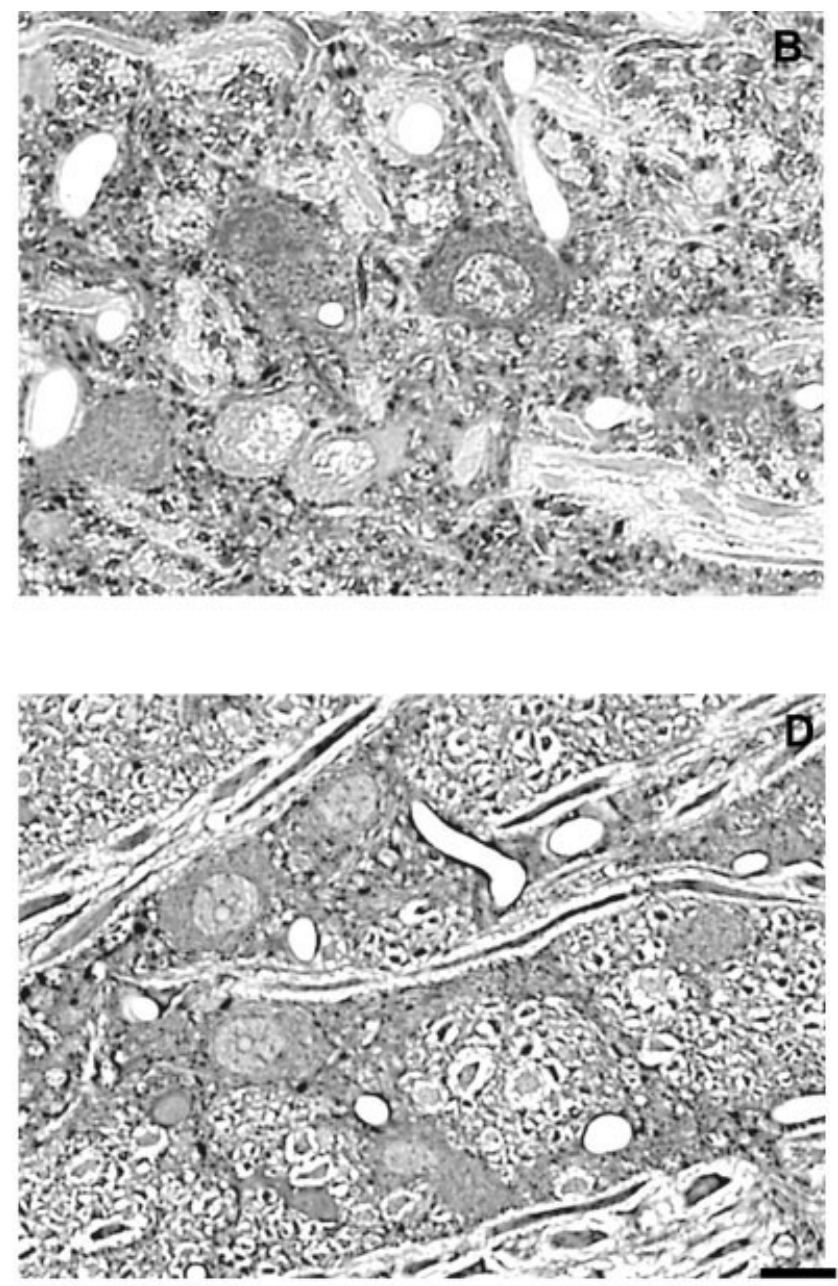

neurons with several Gly-IR puncta surrounding each neuron. Following 14 days of deafness the number of glycine immunoreactive axosomatic puncta significantly decreases. Scale bars $=30 \mu \mathrm{m}$ in $\mathrm{C}$ (applies to A,C); $15 \mu \mathrm{m}$ in D (applies to B,D).
Images were acquired on a Zeiss Axioscope (Thornwood, NY) photomicroscope with a Spot Camera (Diagnostic Instruments, Sterling Heights, MI). Images of the LSO, MNTB, LNTB, VNTB, and SPoN were taken at low magnification using Toluidine blue-stained sections. MetaMorph Imaging software (Universal Imaging, Westchester, PA) was used to designate seven regions of interest (ROIs) across these five nuclei. Rectangular regions were defined in the low-frequency (lateral) and high-frequency (medial) limb or portion of the LSO and SPoN and in the central portion of the MNTB, LNTB, and VNTB. We have previously observed that a large percentage of Gly-IR terminals in the rat MSO are axo-dendritic (Helfert et al., 1989), so this region was not assessed.

Images were then acquired from each individual ROI from the three chosen immunostained sections from each of the five rats in the two groups. All neurons containing nuclei within every ROI on each section were quantitatively assessed using MetaMorph software. Gly-IR puncta were defined by size, $0.05 \mu \mathrm{m}^{2}$ to $4.5 \mu \mathrm{m}^{2}$, shape (ovoidround), intensity of staining (at least $7 \times$ over back- ground), and a location adjacent to the somatic profile. All such Gly-IR puncta immediately adjacent to neuronal somata (thus defined as axo-somatic) were individually counted for every neuron containing a nucleus within the ROI. Each individual neuron was also circled to generate a measure of cross-sectional area and perimeter. StatView software (Cary, NC) was used to perform an analysis of variance (ANOVA) on all axo-somatic puncta and somal size information from each of the 15 sections obtained from the normal group compared to all of the same data obtained from the 15 sections from the deafened group. For each variable measured (somal size and number of puncta), the average was calculated per animal and in those brain regions where high and low frequency were considered, two corresponding averages were calculated per animal. Therefore, the degrees of freedom were equal to 1 in the numerator (deaf vs. normal or high vs. low) and 8 in the denominator (five animals per group, $\mathrm{n}-1$ for each group, normal vs. deaf). A confidence interval of $95 \%$ was used to determine whether observed differences were 

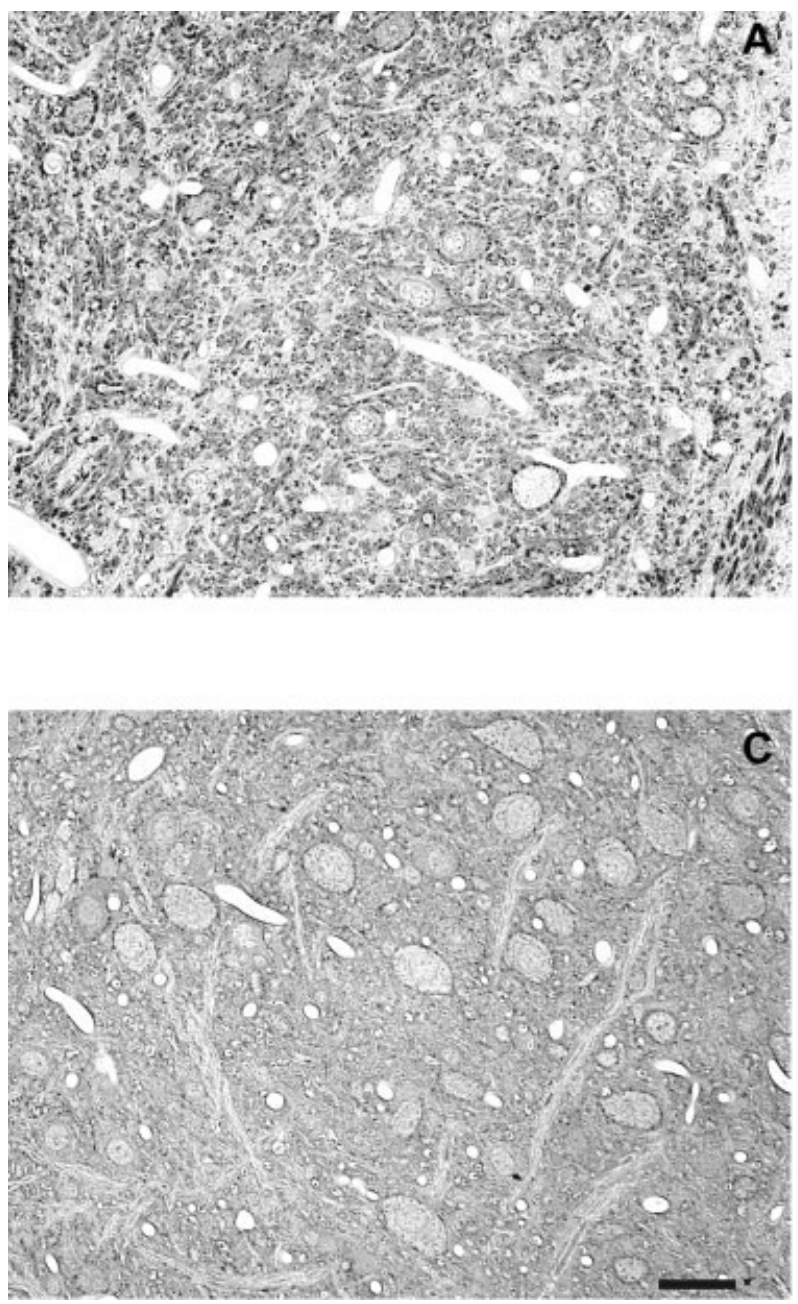

Fig. 3. Representative photomicrographs of Gly-IR staining in the LSO from normal hearing $(\mathbf{A}, \mathbf{B})$ and 14-day deaf $(\mathbf{C , D})$ rats. B and D are enlargements of regions from A and C. In the LSO from normal animals there are both Gly-IR and Gly-immunonegative neurons with
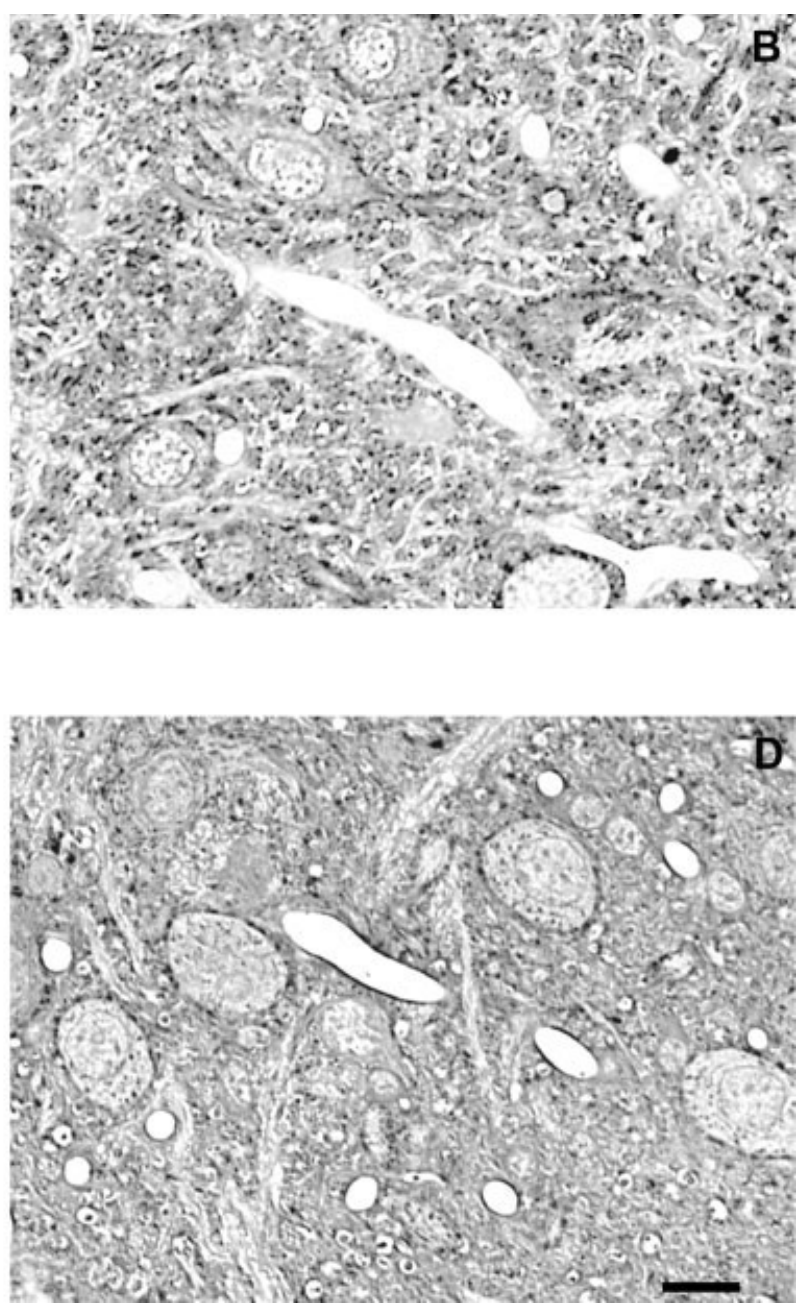

several Gly-IR puncta surrounding each neuron. Following 14 days of deafness the number of glycine immunoreactive axosomatic puncta significantly decreases. Scale bars $=30 \mu \mathrm{m}$ in $\mathrm{C}$ (applies to A,C); 15 $\mu \mathrm{m}$ in $\mathrm{D}$ (applies to B,D). significant. Post-hoc comparisons were performed using a Scheffe test.

Photomicrographs for illustration of results were obtained using a Spot Camera (Diagnostic Instruments) mounted on a Zeiss Axioscope. MetaMorph Imaging software (Universal Imaging) was used to add scale bars to the appropriate images. Each plate of photomicrographs was then assembled in Adobe PhotoShop CS (v. 8, Adobe Systems, San Jose, CA). Brightness and contrast were adjusted without other enhancements to the images.

\section{RESULTS \\ Glycine immunoreactivity (Gly-IR): general}

Glycine immunostaining in the SOC of normal hearing animals was consistent with previous studies (Peyret et al., 1987; Helfert et al., 1989; Adams and Mugnaini, 1990; Henkel and Brunso-Bechtold, 1995; Vater, 1995; Rampon et al., 1996; Ostapoff et al., 1997; Spirou and Berrebi, 1997) (Figs. 1-5). Gly-IR neurons were most numerous in the MNTB, where practically all neurons were immunopositive (Fig. 1A). Numerous Gly-IR neurons were also observed in the VNTB (Fig. 2A), with fewer in the LSO (Fig. $3 \mathrm{~A})$, and still fewer in other SOC regions such as SPoN (Fig. 4A) and LNTB (Fig. 5A). The prevalence of Gly-IR axo-somatic puncta varied among the five subregions of the SOC assessed (Fig. 6). The highest number of Gly-IR axo-somatic puncta was found in the LSO and SPoN, with an intermediate number in the LNTB and VNTB, and the lowest number in the MNTB (Fig. 6). Small differences were found in the number of Gly-IR axo-somatic puncta per $100 \mu \mathrm{m}$ of somatic perimeter between high- and lowfrequency regions in the LSO of normal hearing rats, but not between high- and low-frequency regions in the SPoN (Fig. 6B,C).

\section{Gly-IR axo-somatic puncta in normal hearing versus deafened rats}

LSO. For LSO principal cells the number of Gly-IR puncta per $100 \mu \mathrm{m}$ somatic perimeter was significantly 

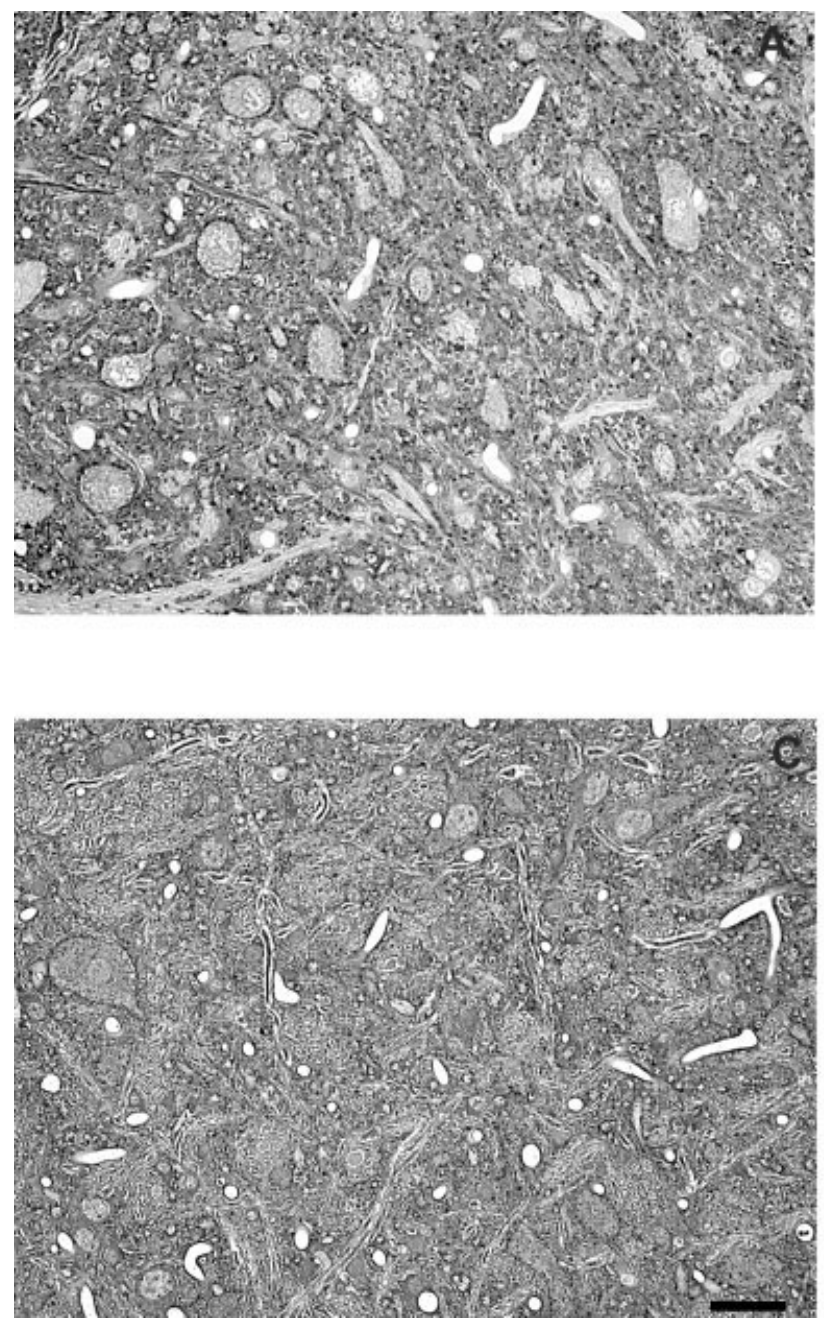

Fig. 4. Representative photomicrographs of Gly-IR staining in the SPoN from normal hearing $(\mathbf{A}, \mathbf{B})$ and 14-day deaf $(\mathbf{C , D})$ rats. B and D are enlargements of regions from $\mathrm{A}$ and $\mathrm{C}$. In the $\mathrm{SPoN}$ from norma animals the neurons are primarily Gly-immunonegative with several

$(P \leq 0.0001)$ lower $(18.8 \pm 0.6)$ in the high-frequency region compared to the low-frequency region $(22.0 \pm 0.5$; Fig. 6B) of normal hearing animals. A significant decrease in Gly-IR puncta at 14 days following deafening was seen in both regions (Fig. 7A). In the high-frequency region there was a significant $(P \leq 0.0001) 25 \%$ decrease from $18.8 \pm 0.6$ in normal hearing to $14.1 \pm 0.7$. In the lowfrequency region there was a significant $(P \leq 0.05) 23 \%$ decrease from $22.2 \pm 0.5$ to $17.2 \pm 1.0$ labeled puncta. The decrease was $24 \%$ when averaged across both regions.

$\boldsymbol{S P o N}$. In the SPoN there was no statistical difference in the number of Gly-IR puncta between the high- and low-frequency regions (Fig. 6C). The number of Gly-IR axo-somatic puncta showed a significant $(P \leq 0.0001)$ change in deafened rats, decreasing $36 \%$ from $19.3 \pm 0.9$ per $100 \mu \mathrm{m}$ perimeter to $12.1 \pm 0.8$ in deafened animals in high-frequency regions with a comparable change $(P \leq$ 0.0001 ) from $18.1 \pm 1.1$ per $100 \mu \mathrm{m}$ perimeter to $12.7 \pm$ 0.9 in the low-frequency area (Fig. 7B).

MNTB. MNTB neurons had by far the fewest number Gly-IR axo-somatic puncta (Fig. 6A) in normal hearing
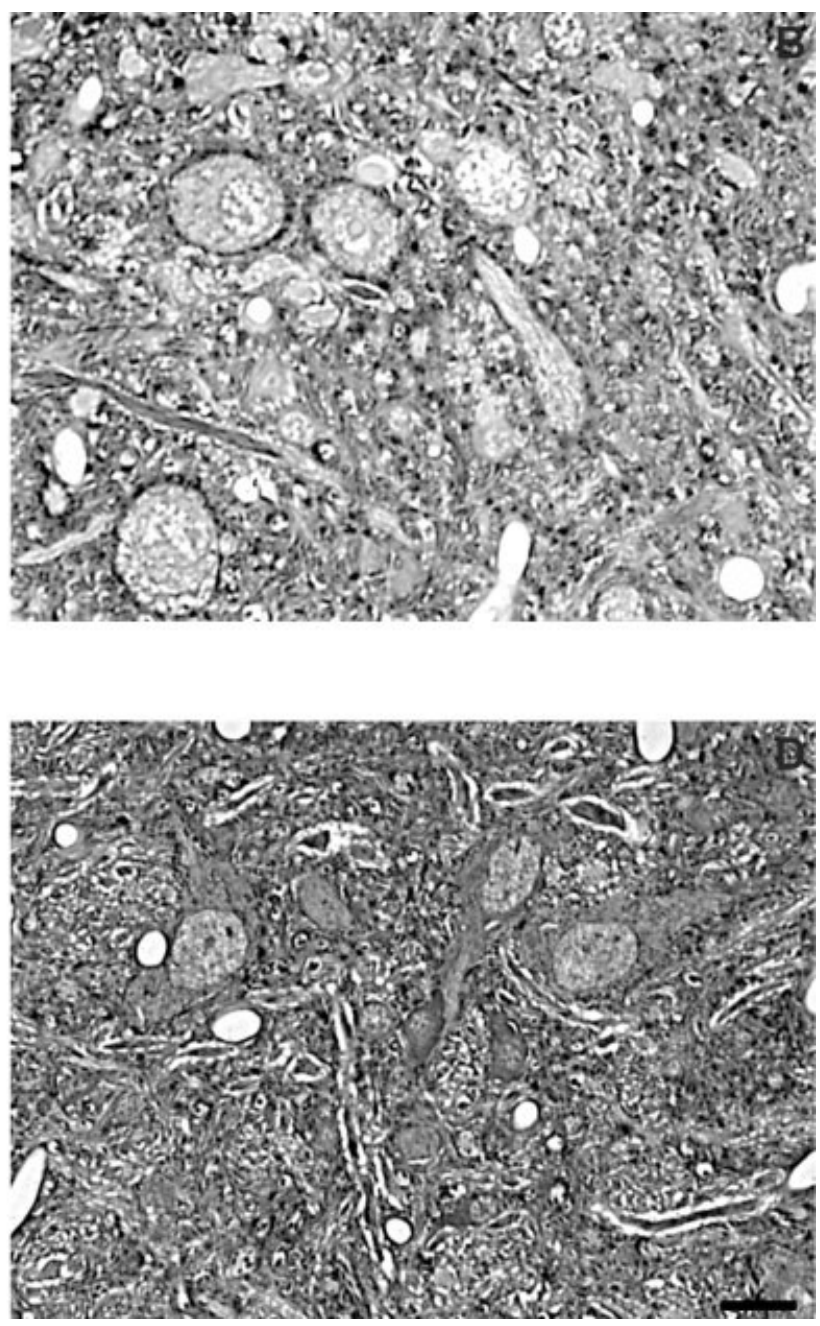

Gly-IR puncta surrounding each neuron. Following 14 days of deafness the number of glycine immunoreactive axosomatic puncta significantly decreases. Scale bars $=30 \mu \mathrm{m}$ in $\mathrm{C}$ (applies to A,C); $15 \mu \mathrm{m}$ in $\mathrm{D}$ (applies to $\mathrm{B}, \mathrm{D})$.

and deafened animals. In normal hearing animals the number of puncta averaged $6.6 \pm 0.3$ per $100 \mu \mathrm{m}$ perimeter, $35 \%$ of that found for LSO neurons. The number of Gly-IR puncta per cell profile decreased $(P \leq 0.001) 35 \%$ following deafness, to $4.3 \pm 0.2$ Gly-IR axo-somatic puncta per $100 \mu \mathrm{m}$ perimeter (Fig. 7C).

VNTB. The VNTB of normal hearing rats had $13.8 \pm$ 1.7 Gly-IR axo-somatic puncta per $100 \mu \mathrm{m}$ perimeter (Fig. $6 \mathrm{~A})$. There was a significant $(P \leq 0.01)$ almost $50 \%$ decrease following deafness, with the number of puncta per $100 \mu \mathrm{m}$ perimeter decreasing to $7.4 \pm 0.7$ (Fig. 7D).

LNTB. LNTB neurons had $15.4 \pm 0.8$ Gly-IR axosomatic puncta per $100 \mu \mathrm{m}$ perimeter (Fig. 6A). There was a significant $(P \leq 0.01) 29 \%$ decrease, to $11.0 \pm 0.8 \mathrm{Gly}-\mathrm{IR}$ axo-somatic puncta per $100 \mu \mathrm{m}$ perimeter in the LNTB of deafened rats (Fig. 7E).

\section{Cell size}

Cell size of principal cells in each region was compared between normal hearing and deafened animals. While a decrease in the size of MNTB principal cells has been 

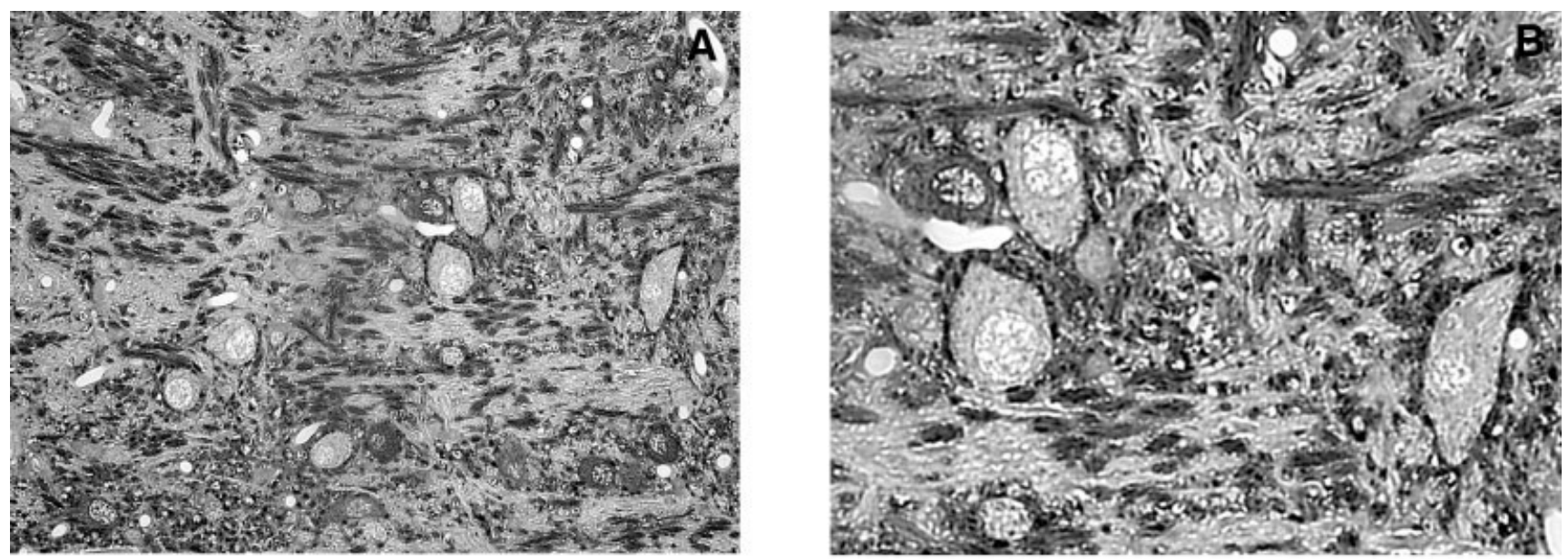

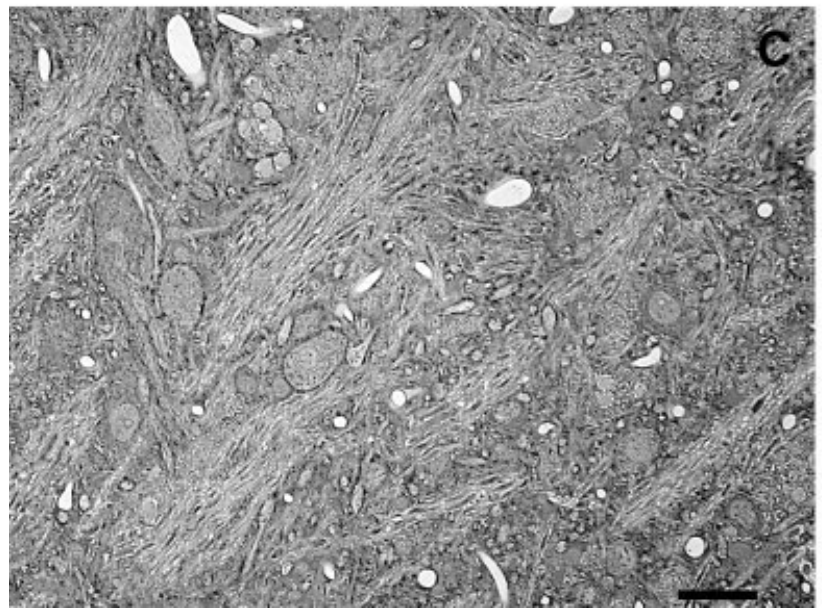

Fig. 5. Representative photomicrographs of Gly-IR staining in the LNTB from normal hearing $(\mathbf{A}, \mathbf{B})$ and 14-day deaf $(\mathbf{C , D})$ rats. B and $\mathrm{D}$ are enlargements of regions from A and C. In the LNTB from normal animals there is a mixture of Gly-IR and Gly-immunonegative

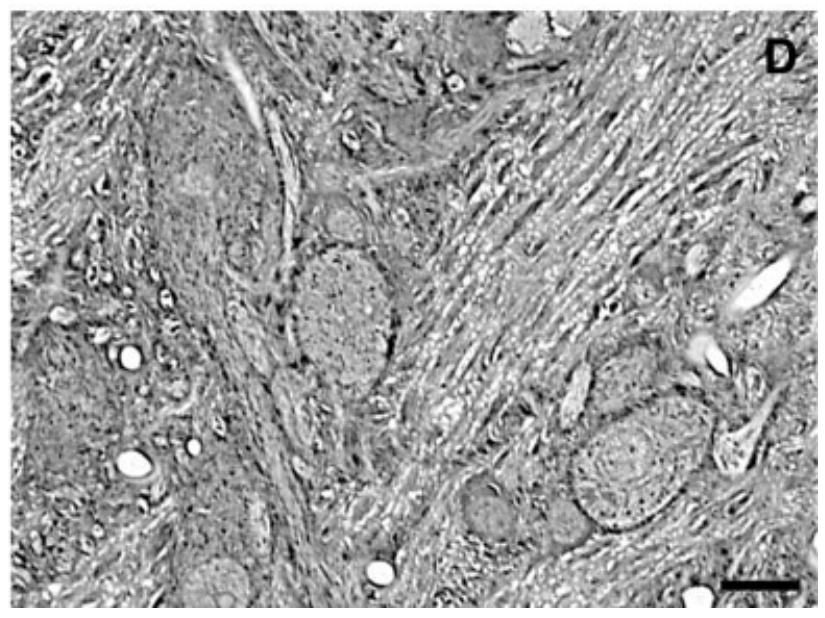

neurons with several Gly-IR puncta surrounding each neuron. Following 14 days of deafness the number of glycine immunoreactive axosomatic puncta significantly decreases. Scale bars $=30 \mu \mathrm{m}$ in $\mathrm{C}$ (applies to A,C); $15 \mu \mathrm{m}$ in D (applies to B,D). reported previously (Pasic et al., 1994), no significant change was found in the present study, although there was a trend towards a decrease (9\%) from $255.9 \pm 12.2$ $\mu \mathrm{m}^{2}$ for MNTB principal cells in normal hearing animals to $233.0 \pm 6.1 \mu^{2}$ following deafness. In the LSO of normal hearing animals, the principal cells in the highfrequency region were significantly larger $(P=0.05)$ than neurons in the low-frequency region of normal animals (high frequency $=58.8 \pm 0.96{\mu \mathrm{m}^{2}}^{2}$, low frequency $=$ $54.7 \pm 1.3 \mu \mathrm{m}^{2}$ ), as described previously (Rietzel and Friauf, 1998; Sanes et al., 1992). LSO neurons, however, did not show any significant change in size following deafness, nor were any significant changes found in principal cells of SPoN, VNTB, and LNTB.

\section{DISCUSSION}

The present study showed a deafness-related decrease in the number of Gly-IR puncta on the somata of principal cells in all five SOC nuclei evaluated. This is consistent with previous reports of deafness-associated decreases in Gly-IR cells and terminals in the cochlear nucleus (CN) (Willott and Turner, 1999, 2000). The decrease in labeled puncta could be a consequence of a decrease in glycine levels within some terminals, bringing them below the level of immunocytochemical detection, but still present. On the other hand, it could also reflect a physical reduction in the number of glycine-containing terminals making contact with somata. Such changes in terminals have been reported in the cochlear nucleus following noiserelated hearing loss (Kim et al., 2004a-c). During development there is experience-dependent plasticity that involves extensive "pruning" or "trimming" of glycinergic terminals in both the MSO and LSO (Sanes and Takacs, 1993; Kandler and Friauf, 1995; Sanes and Friauf, 2000; Kapfer et al., 2002; Kim and Kandler, 2003). There could also be an "activity-dependent" decrease following deafness, associated with decreased activity. It is also possible that there is even a readjustment in the location of glycine-immunoreactive terminals, with terminals mov- 
A Number of Puncta Per $100 \mu \mathrm{m}$ perimeter in SOC Nuclei

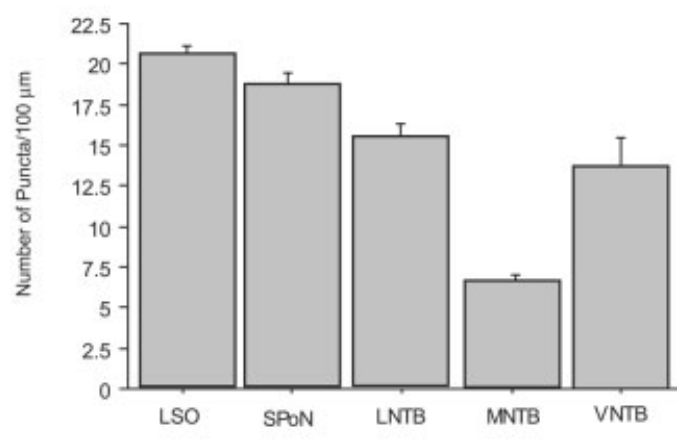

B Number of Puncta Per $100 \mu \mathrm{m}$ perimeter in LSO
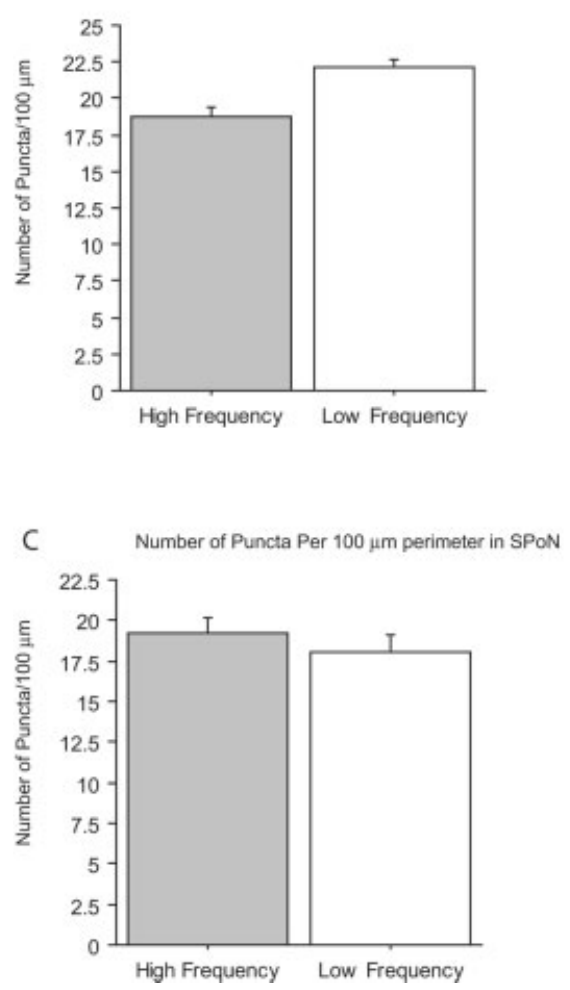

Fig. 6. Average number of axo-somatic Gly-IR puncta per $100 \mu \mathrm{m}$ of cell perimeter in SOC nuclei of normal hearing animals. In the five animals assessed, the LSO and SPoN were divided into high- and low-frequency regions. Of the neurons examined in each of the five nuclei the LSO ( $\mathrm{n}=255$ high-frequency compared to 223 lowfrequency neurons) and SPoN ( $\mathrm{n}=125$ high-frequency compared to 93 low-frequency neurons) had the largest average number of glycine immunoreactive puncta, followed by neurons in the LNTB ( $\mathrm{n}=198$ neurons), MNTB ( $\mathrm{n}=315)$, and VNTB ( $\mathrm{n}=143$ neurons). Error bars are SEM.

ing from somata to dendrites, similar to the experiencedependent changes Kapfer et al. (2002) reported in the medial superior olive during development. While we did not quantitatively assess glycine-immunolabeled puncta in the neuropil (corresponding to axo-dendritic terminals and cross-cut axons) in the present study, qualitatively they appeared to decrease in a comparable fashion as axo-somatic puncta rather than increase. Postembedding immunocytochemistry for glycine characterized by electron microscopy and adding flattened vesicles as a second metric for glycine containing terminals would help to resolve these issues.

Suneja et al. (1998) found that unilateral deafening, by cochlear ablation, produced decreases in glycine release in the cochlear nucleus but not in the LSO or MNTB. Since the SOC receives input from both ears, a bilateral deafening (as we used in the present study) may be necessary to produce changes in glycine levels in these regions. It is also possible that the $25 \%$ decrease in axo-somatic puncta we observed in the LSO may not be resolved when measuring release across a whole LSO preparation, as in Suneja et al. (1998), although it could still impact release at the level of the individual synapse. Also, differences in the method of deafening (cochlear ablation vs. intrascalar neomycin) or differences in the assessment times following deafness cannot be ruled out as contributing factors to the differences found when comparing these two results. Recent results from Suneja and Potashner (2003a) suggest that deafness may influence the intracellular pathways that modulate neurotransmitters and their release and, perhaps, a more effective release mechanism could compensate for less neurotransmitter available for release.

Our results showed differences in the percent decrease of Gly-IR axo-somatic puncta across SOC nuclei, ranging from a decrease of just under $50 \%$ in the VNTB to $\sim 20 \%$ in the LNTB. Glycine is a major inhibitory influence in the SOC, with much of the glycinergic pathway originating in the MNTB, with a smaller contribution from the LNTB (Cant and Hyson, 1992; Kuwabara and Zook, 1992; Wu and Kelly, 1994; Spirou and Berrebi, 1997). SOC neurons receive both ipsilateral and contralateral glycinergic input, with ipsilateral input predominating (Wu and Kelly, 1991, 1992, 1994; Cant and Hyson, 1992; Grothe and Sanes, 1993; Smith et al., 2000; Brand et al., 2002; Srinivasan et al., 2004). In the LSO the balance between glutamatergic excitation from the cochlear nucleus and glycinergic inhibition is important for detection of interaural level differences (ILD) (Moore and Caspary, 1983; Finlayson and Adam, 1997; Irvine et al., 2001, for reviews). The response of LSO neurons to glycine can be biphasic. Green et al. (2003) reported glycine produced an initial hyperpolarization of LSO neurons followed by depolarization that could be related to an influence on their intracellular $\mathrm{pH}$. An important role has also recently emerged for the glycinergic input onto MSO, where the interaural time difference (ITD) tuning is dependent not only on the timing of excitatory glutamatergic input from contra- and ipsilateral $\mathrm{CN}$, but also on the precise timing of glycinergic inhibitory inputs which also function to adjust the slope of ITD functions (Grothe, 1994, 2003; Grothe and Sanes, 1994; Brand et al., 2002). With distinctly different functions contributing to ITD discrimination in MSO and ILD discrimination in LSO and still additional functions suggested in the SPoN (Behrend et al., 2002; Dehmel et al., 2002; Kulesza et al., 2003), as well as at least two different sources, we expect that glycinergic terminals would have different changes following deafness in different SOC nuclei. Lim et al. (2003) reported site-to-site variability in glycinergic synapses in the MNTB based on glycinergic mIPSC amplitudes, which they suggested could be due to presynaptic differences (increased rate of release) as well 

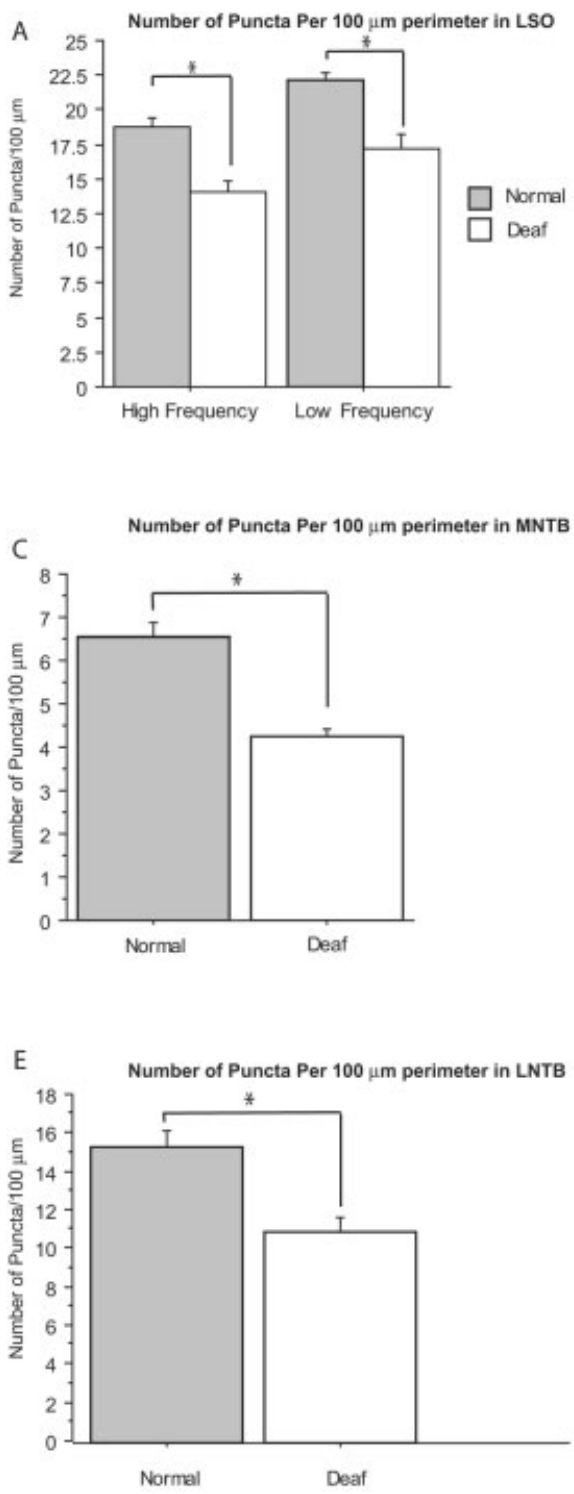

Fig. 7. Comparison of the average number of axo-somatic Gly-IR puncta per $100 \mu \mathrm{m}$ of cell perimeter in normal hearing and 14-day deaf animals in the different SOC nuclei. For each nucleus a comparable number of neurons was examined in the LSO ( $\mathrm{n}=223$ lowfrequency neurons in normal, 222 low-frequency neurons in deaf, 255 high-frequency neurons in normal, and 248 high-frequency neurons in deaf), SPoN ( $\mathrm{n}=93$ low-frequency neurons in normal, 131 low-

as postsynaptic receptor clustering. Determining whether these or other synaptic differences correlate with the remaining detectable glycinergic terminals following deafness would be of great interest.

Brand et al. (2002) suggested that age-related loss of inhibitory transmitters in the SOC, such as reported by Willot and colleagues (Willott and Turner, 1999; Willott et al., 2000) in the $\mathrm{CN}$, could explain age-related hearing deficits such as a decreased ability to segregate sounds. Decreases in glycine levels following profound deafness, as found in the present study, could have a comparable effect if and when hearing is returned via a cochlear prosthesis.
B
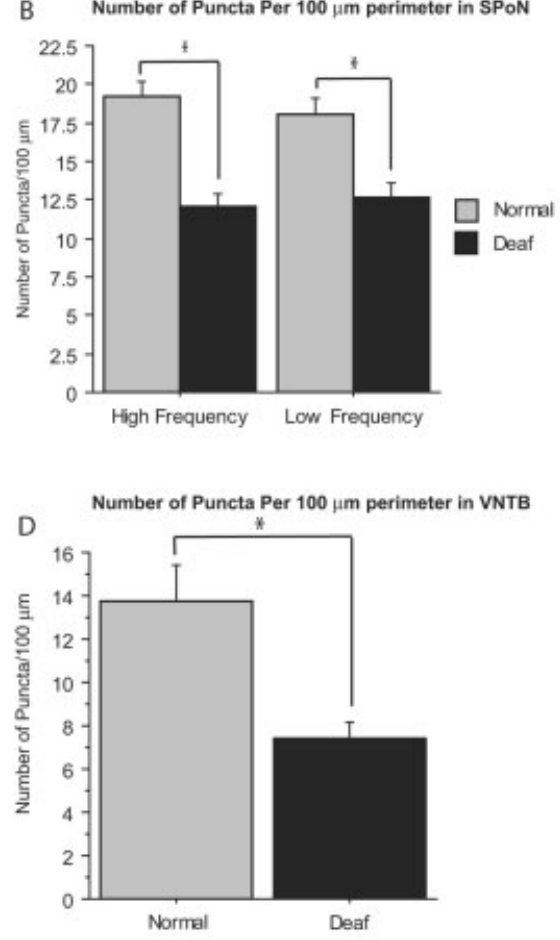

frequency neurons in deaf, 126 high-frequency neurons in normal, and 106 high-frequency neurons in deaf), LNTB $(n=198$ neurons in normal and 127 neurons in deaf), MNTB ( $\mathrm{n}=315$ neurons in normal and 282 neurons in deaf), and VNTB ( $\mathrm{n}=143$ neurons in normal and 135 neurons in deaf). Error bars are SEM and asterisks denote significance of $P \leq 0.05$.

A reduced ability to segregate sounds through binaural interaction in the SOC would probably not have an impact on the monaural hearing that is produced when the profoundly deaf receive a unilateral cochlear prosthesis, which is currently the most common situation. On the other hand, more patients are now receiving bilateral cochlear prostheses and in this case deafness-induced decreases in glycine terminals, such as we found in the present study, could result in a reduced capacity for segregating sounds. Another conceivable outcome is that a return of activity could reverse the decreases in glycine induced by the loss of activity due to deafness, resulting in 
a return to normal processing. Future studies to examine the reversal of deafness-induced decreases in glycine following return of activity and comparing monaural versus binaural cochlear electrical stimulation could help to resolve this issue and increase our understanding of the impact that changes in glycine levels have on processing.

\section{LITERATURE CITED}

Adams JC, Mugnaini E. 1990. Immunocytochemical evidence for inhibitory and disinhibitory circuits in the superior olive. Hear Res 49:281-298.

Behrend O, Brand A, Kapfer C, Grothe B. 2002. Auditory response properties in the superior paraolivary nucleus of the gerbil. J Neurophysiol 87:2915-2928.

Benson CG, Gross JS, Suneja SK, Potashner SJ. 1997. Synaptophysin immunoreactivity in the cochlear nucleus after unilateral cochlear or ossicular removal. Synapse 25:243-257.

Bledsoe SC Jr, Nagase S, Miller JM, Altschuler RA. 1995. Deafnessinduced plasticity in the mature central auditory system. Neuroreport 7:225-229.

Brand A, Behrend O, Marquardt T, McAlpine D, Grothe B. 2002. Precise inhibition is essential for microsecond interaural time difference coding. Nature 417:543-547.

Cant NB, Hyson RL. 1992. Projections from the lateral nucleus of the trapezoid body to the medial superior olivary nucleus in the gerbil. Hear Res 58:26-34.

Caspary DM, Pazara KE, Kossl M, Faingold CL. 1987. Strychnine alters the fusiform cell output from the dorsal cochlear nucleus. Brain Res 417:273-282.

Caspary DM, Backoff PM, Finlayson PG, Palombi PS. 1994. Inhibitory inputs modulate discharge rate within frequency receptive fields of anteroventral cochlear nucleus neurons. J Neurophysiol 72:21242133.

Caspary DM, Milbrandt JC, Helfert RH. 1995. Central auditory aging: GABA changes in the inferior colliculus. Exp Gerontol 30:349-360.

Caspary DM, Holder TM, Hughes LF, Milbrandt JC, McKernan RM, Naritoku DK. 1999. Age-related changes in GABA(A) receptor subunit composition and function in rat auditory system. Neuroscience 93:307312 .

Dehmel S, Kopp-Scheinpflug C, Dorrscheidt GJ, Rubsamen R. 2002. Electrophysiological characterization of the superior paraolivary nucleus in the Mongolian gerbil. Hear Res 172:18-36.

Finlayson PG, Adam TJ. 1997. Excitatory and inhibitory response adaptation in the superior olive complex affects binaural acoustic processing. Hear Res 103:1-18.

Francis HW, Manis PB. 2000. Effects of deafferentation on the electrophysiology of ventral cochlear nucleus neurons. Hear Res 149:91-105.

Garcia MM, Edward R, Brennan GB, Harlan RE. 2000. Deafferentationinduced changes in protein kinase $\mathrm{C}$ expression in the rat cochlear nucleus. Hear Res 147:113-124.

Green JS, Kotak VC, Sanes DH. 2003. Glycine mediated alterations in intracellular pH. Brain Res 989:122-127.

Grothe B. 1994. Interaction of excitation and inhibition in processing of pure tone and amplitude-modulated stimuli in the medial superior olive of the mustached bat. J Neurophysiol 71:706-721.

Grothe B. 2003. New roles for synaptic inhibition in sound localization. Nat Rev Neurosci 4:540-550.

Grothe B, Sanes DH. 1993. Bilateral inhibition by glycinergic afferents in the medial superior olive. J Neurophysiol 69:1192-1196.

Grothe B, Sanes DH. 1994. Synaptic inhibition influences the temporal coding properties of medial superior olivary neurons: an in vitro study. J Neurosci 14:1701-1709.

Helfert RH, Bonneau JM, Wenthold RJ, Altschuler RA. 1989. GABA and glycine immunoreactivity in the guinea pig superior olivary complex. Brain Res 501:269-286.

Helfert RH, Sommer TJ, Meeks J, Hofstetter P, Hughes LF. 1999. Agerelated synaptic changes in the central nucleus of the inferior colliculus of Fischer-344 rats. J Comp Neurol 406:285-298.

Henkel CK, Brunso-Bechtold JK. 1995. Development of glycinergic cells and puncta in nuclei of the superior olivary complex of the postnatal ferret. J Comp Neurol 354:470-480.

Holt AG, Asako M, Lomax CA, MacDonald JW, Tong L, Lomax MI, Altschuler RA. 2005. Deafness related plasticity in the inferior colliculus: gene expression profiling following removal of peripheral activity. J Neurochem 93:1069-1086.

Idrizbegovic E, Bogdanovic N, Canlon B. 1998. Modulating calbindin and parvalbumin immunoreactivity in the cochlear nucleus by moderate noise exposure in mice. A quantitative study on the dorsal and posteroventral cochlear nucleus. Brain Res 800:86-96.

Illing RB, Michler SA. 2001. Modulation of P-CREB and expression of c-fos in cochlear nucleus and superior olive following electrical intracochlear stimulation. Neuroreport 12:875-878.

Irvine DR, Park VN, McCormick L. 2001. Mechanisms underlying the sensitivity of neurons in the lateral superior olive to interaural intensity differences. J Neurophysiol 86:2647-2666.

Kalloniatis M, Fletcher EL. 1993. Immunocytochemical localization of the amino acid neurotransmitters in the chicken retina. J Comp Neurol 336:174-193.

Kaltenbach JA, Afman CE. 2000. Hyperactivity in the dorsal cochlear nucleus after intense sound exposure and its resemblance to toneevoked activity: a physiological model for tinnitus. Hear Res 140:165172 .

Kandler K, Friauf E. 1995. Development of glycinergic and glutamatergic synaptic transmission in the auditory brainstem of perinatal rats. J Neurosci 15:6890-6904.

Kapfer C, Seidl AH, Schweizer H, Grothe B. 2002. Experience-dependent refinement of inhibitory inputs to auditory coincidence-detector neurons. Nat Neurosci 5:247-253.

Kim G, Kandler K. 2003. Elimination and strengthening of glycinergic/ GABAergic connections during tonotopic map formation. Nat Neurosc 6:282-290.

Kim JJ, Gross J, Morest DK, Potashner SJ. 2004a. Quantitative study of degeneration and new growth of axons and synaptic endings in the chinchilla cochlear nucleus after acoustic overstimulation. J Neurosci Res 77:829-842.

Kim JJ, Gross J, Potashner SJ, Morest DK. 2004b. Fine structure of degeneration in the cochlear nucleus of the chinchilla after acoustic overstimulation. J Neurosci Res 77:798-816.

Kim JJ, Gross J, Potashner SJ, Morest DK. 2004c. Fine structure of long-term changes in the cochlear nucleus after acoustic overstimulation: chronic degeneration and new growth of synaptic endings. J Neurosci Res 77:817-828.

Kulesza RJ Jr, Spirou GA, Berrebi AS. 2003. Physiological response properties of neurons in the superior paraolivary nucleus of the rat. J Neurophysiol 89:2299-2312.

Kuwabara N, Zook JM. 1992. Projections to the medial superior olive from the medial and lateral nuclei of the trapezoid body in rodents and bats. J Comp Neurol 324:522-538.

Lim R, Oleskevich S, Few AP, Leao RN, Walmsley B. 2003. Glycinergic mIPSCs in mouse and rat brainstem auditory nuclei: modulation by ruthenium red and the role of calcium stores. J Physiol 546:691-699.

Lu Y, Monsivais P, Tempel BL, Rubel EW. 2004. Activity-dependent regulation of the potassium channel subunits Kv1.1 and Kv3.1. J Comp Neurol 470:93-106.

Macica CM, von Hehn CA, Wang LY, Ho CS, Yokoyama S, Joho RH, Kaczmarek LK. 2003. Modulation of the kv3.1b potassium channel isoform adjusts the fidelity of the firing pattern of auditory neurons. J Neurosci 23:1133-1141.

Milbrandt JC, Hunter C, Caspary DM. 1997. Alterations of GABAA receptor subunit mRNA levels in the aging Fischer 344 rat inferior colliculus. J Comp Neurol 379:455-465.

Møller AR. 2001. Symptoms and signs caused by neural plasticity. Neurol Res 23:565-572.

Møller AR. 2005. Anatomical and physiological basis for neural plasticity. In: Neural plasticity and disorders of the nervous system. New York: Cambridge University Press. p 1-38.

Moore MJ, Caspary DM. 1983. Strychnine blocks binaural inhibition in lateral superior olivary neurons. J Neurosci 3:237-242.

Mossop JE, Wilson MJ, Caspary DM, Moore DR. 2000. Down-regulation of inhibition following unilateral deafening. Hear Res 147:183-187.

Nagase S, Miller JM, Dupont J, Lim HH, Sato K, Altschuler RA. 2000. Changes in cochlear electrical stimulation induced Fos expression in the rat inferior colliculus following deafness. Hear Res 147:242-250.

Nakagawa H, Sato K, Shiraishi Y, Kuriyama H, Altschuler RA. 2000. NMDAR1 isoforms in the rat superior olivary complex and changes after unilateral cochlear ablation. Brain Res Mol Brain Res 77:246257.

Ostapoff EM, Benson CG, Saint Marie RL. 1997. GABA- and glycine- 
immunoreactive projections from the superior olivary complex to the cochlear nucleus in guinea pig. J Comp Neurol 381:500-512.

Pasic TR, Moore DR, Rubel EW. 1994. Effect of altered neuronal activity on cell size in the medial nucleus of the trapezoid body and ventral cochlear nucleus of the gerbil. J Comp Neurol 348:111-120.

Peyret D, Campistron G, Geffard M, Aran JM. 1987. Glycine immunoreactivity in the brainstem auditory and vestibular nuclei of the guinea pig. Acta Otolaryngol 104:71-76.

Potashner SJ, Suneja SK, Benson CG. 1997. Regulation of D-aspartate release and uptake in adult brain stem auditory nuclei after unilateral middle ear ossicle removal and cochlear ablation. Exp Neurol 148:222235.

Potashner SJ, Suneja SK, Benson CG. 2000. Altered glycinergic synaptic activities in guinea pig brain stem auditory nuclei after unilateral cochlear ablation. Hear Res 147:125-136.

Rajan R, Irvine DR. 1998. Neuronal responses across cortical field A1 in plasticity induced by peripheral auditory organ damage. Audiol Neurootol 3:123-144.

Rampon C, Luppi PH, Fort P, Peyron C, Jouvet M. 1996. Distribution of glycine-immunoreactive cell bodies and fibers in the rat brain. Neuroscience 75:737-755.

Rietzel HJ, Friauf E. 1998. Neuron types in the rat lateral superior olive and developmental changes in the complexity of their dendritic arbors. J Comp Neurol 390:20-40.

Robertson D, Irvine DR. 1989. Plasticity of frequency organization in auditory cortex of guinea pigs with partial unilateral deafness. J Comp Neurol 282:456-471.

Ryugo DK, Rosenbaum BT, Kim PJ, Niparko JK, Saada AA. 1998. Single unit recordings in the auditory nerve of congenitally deaf white cats: morphological correlates in the cochlea and cochlear nucleus. J Comp Neurol 397:532-548.

Salvi RJ, Wang J, Ding D, Stecker N, Arnold S. 1999. Auditory deprivation of the central auditory system resulting from selective inner hair cell loss: animal model of auditory neuropathy. Scand Audiol Suppl 51:112 .

Salvi RJ, Wang J, Ding D. 2000. Auditory plasticity and hyperactivity following cochlear damage. Hear Res 147:261-274.

Sanes DH, Friauf E. 2000. Development and influence of inhibition in the lateral superior olivary nucleus. Hear Res 147:46-58.

Sanes DH, Takacs C. 1993. Activity-dependent refinement of inhibitory connections. Eur J Neurosci 5:570-574.

Sanes DH, Song J, Tyson J. 1992. Refinement of dendritic arbors along the tonotopic axis of the gerbil lateral superior olive. Brain Res Dev Brain Res 67:47-55.

Sato K, Kuriyama H, Altschuler RA. 2000a. Expression of glycine receptor subunit mRNAs in the rat cochlear nucleus. Hear Res 144:47-52.

Sato K, Shiraishi S, Nakagawa H, Kuriyama H, Altschuler RA. 2000b. Diversity and plasticity in amino acid receptor subunits in the rat auditory brain stem. Hear Res 147:137-144.

Schwartz DR, Schacht J, Miller JM, Frey K, Altschuler RA. 1993. Chronic electrical stimulation reverses deafness-related depression of electrically evoked 2-deoxyglucose activity in the guinea pig inferior colliculus. Hear Res 70:243-249.

Smith AJ, Owens S, Forsythe ID. 2000. Characterisation of inhibitory and excitatory postsynaptic currents of the rat medial superior olive. J Physiol 529:681-698.
Spirou GA, Berrebi AS. 1997. Glycine immunoreactivity in the lateral nucleus of the trapezoid body of the cat. J Comp Neurol 383:473-488.

Srinivasan G, Friauf E, Lohrke S. 2004. Functional glutamatergic and glycinergic inputs to several superior olivary nuclei of the rat revealed by optical imaging. Neuroscience 128:617-634.

Suneja SK, Potashner SJ. 2003. ERK and SAPK signaling in auditory brainstem neurons after unilateral cochlear ablation. J Neurosci Res 73:235-245.

Suneja SK, Benson CG, Potashner SJ. 1998. Glycine receptors in adult guinea pig brain stem auditory nuclei: regulation after unilateral cochlear ablation. Exp Neurol 154:473-488.

Syka J. 2002. Plastic changes in the central auditory system after hearing loss, restoration of function, and during learning. Physiol Rev 82:601636.

Syka J, Rybalko N. 2000. Threshold shifts and enhancement of cortical evoked responses after noise exposure in rats. Hear Res 139:59-68.

Syka J, Popelar J, Kvasnak E, Astl J. 2000. Response properties of neurons in the central nucleus and external and dorsal cortices of the inferior colliculus in guinea pig. Exp Brain Res 133:254-266.

Vale C, Sanes DH. 2002. The effect of bilateral deafness on excitatory and inhibitory synaptic strength in the inferior colliculus. Eur J Neurosci 16:2394-2404.

Vater M. 1995. Ultrastructural and immunocytochemical observations on the superior olivary complex of the mustached bat. J Comp Neurol 358:155-180.

von Hehn CA, Bhattacharjee A, Kaczmarek LK. 2004. Loss of Kv3.1 tonotopicity and alterations in cAMP response element-binding protein signaling in central auditory neurons of hearing impaired mice. J Neurosci 24:1936-1940.

Wickesberg RE, Oertel D. 1990. Delayed, frequency-specific inhibition in the cochlear nuclei of mice: a mechanism for monaural echo suppression. J Neurosci 10:1762-1768.

Willott JF, Turner JG. 1999. Prolonged exposure to an augmented acoustic environment ameliorates age-related auditory changes in C57BL/6J and DBA/2J mice. Hear Res 135:78-88.

Willott JF, Turner JG. 2000. Neural plasticity in the mouse inferior colliculus: relationship to hearing loss, augmented acoustic stimulation, and prepulse inhibition. Hear Res 147:275-281.

Willott JF, Demuth RM, Lu SM, Van Bergem P. 1982. Abnormal tonotopic organization in the ventral cochlear nucleus of the hearing-impaired DBA/2 mouse. Neurosci Lett 34:13-17.

Willott JF, Aitkin LM, McFadden SL. 1993. Plasticity of auditory cortex associated with sensorineural hearing loss in adult C57BL/6J mice. J Comp Neurol 329:402-411.

Willott JF, Turner JG, Sundin VS. 2000. Effects of exposure to an augmented acoustic environment on auditory function in mice: roles of hearing loss and age during treatment. Hear Res 142:79-88.

Wu SH, Kelly JB. 1991. Physiological properties of neurons in the mouse superior olive: membrane characteristics and postsynaptic responses studied in vitro. J Neurophysiol 65:230-246.

Wu SH, Kelly JB. 1992. Binaural interaction in the lateral superior olive: time difference sensitivity studied in mouse brain slice. J Neurophysiol 68:1151-1159.

Wu SH, Kelly JB. 1994. Physiological evidence for ipsilateral inhibition in the lateral superior olive: synaptic responses in mouse brain slice. Hear Res 73:57-64. 